\title{
Impacts of Climate Change and Water Resources Development on the Declining Inflow into Iran's Urmia Lake
}

\author{
Somayeh Shadkam ${ }^{1,3^{*}}$, Fulco Ludwig ${ }^{1}$, Pieter van $\mathrm{Oel}^{2}$, Çăgla Kirmit ${ }^{1}$, Pavel Kabat ${ }^{1,3}$
}

[1] Earth System Science-Climate Change and Adaptive Land and Water Management, Wageningen

University and Research Centre, PO Box 47, 6700 AA Wageningen, The Netherlands

[2] Water Resources Management group, Wageningen University and Research Centre, Wageningen, The

Netherlands

[3] The International Institute for Applied Systems Analysis (IIASA), Laxenburg, Austria

Correspondence to: E-mail: somayeh.shadkam@wur.nl, Phone: + 31317483 499, Fax: +31 317419000

\begin{abstract}
Urmia Lake, the world second largest hypersaline lake, has decreased in size over recent decades primarily because inflow has diminished. This has caused serious socio-environmental consequences similar to those of the Aral Sea disaster. By using the Variable Infiltration Capacity (VIC) model, this study estimates the relative contributions of climate change and water resources development - which includes construction of reservoirs and expansion of irrigated areas - to changes in Urmia Lake inflow over the period 1960-2010. The model results show that decreases in inflow generally follow observed decreases in precipitation, though the variability in inflow is more pronounced than the variability in precipitation. The results also suggest that water use for irrigation has increased pressure on the basin's water availability and has caused flows to decrease by as much as $40 \%$ during dry years. On the other hand, the presence of reservoirs positively contributed to water availability during relatively dry years and did not significantly reduce lake inflow. By accelerating irrigation expansion in the basin, reservoirs have, however indirectly, contributed to inflow reduction. Our results show that annual inflow to Urmia Lake has dropped by $48 \%$ over the study period. About three fifths of this change was caused by climate change and about two fifths was caused by water resources development. The results of this study show that to prevent further desiccation of Urmia Lake it will be necessary both to develop national plans to reduce irrigation water use and to develop international plans to address climate change.
\end{abstract}

Keywords: Urmia Lake, Hypersaline Lake, Water Resources Development, Reservoirs, Irrigation, Climate Change and Variability 


\section{Introduction}

Climate change ${ }^{1}$ significantly influences the natural hydrological cycle which can contribute to water scarcity (Haddeland et al., 2014; IPCC, 2014). To safeguard water and food supplies for growing population, humans construct reservoirs, extract water for irrigation and modify land use. These actions have been associated with an increasing number of drying lakes in arid and semi-arid areas (IPCC, 2014). However, only a limited number of studies have assessed the role of climate change and water resources development, individually and combined, on the desiccation of lakes. This knowledge gap hampers our ability to develop adequate and effective adaptation strategies to rehabilitate and preserve endangered lakes. Among all vulnerable lakes, the saline and hypersaline lakes need particular attention due to their highly vulnerable ecosystems and the irreversible socio-environmental impacts of their desiccation. In this paper, we evaluate the impact of climate change and water resources development on the desiccation of the world's second largest permanent hypersaline lake, Urmia Lake (Karbassi et al., 2010).

Urmia Lake basin is located in the northwest of Iran and has been seriously affected by both climate change and water resources development (Farokhnia, 2015; Fathian et al., 2014; Hassanzadeh et al., 2012). The Urmia Lake basin is an important agricultural region with a population of around 6 million people. The lake's water level and surface area have sharply declined over the last two decades (Kakahaji et al., 2013). This has caused an environmental disaster by increased salinity and has had negative effects on ecosystems, agriculture, livelihoods, and health (Karbassi et al., 2010). An outcome similar to that observed in the Aral Sea is likely for this lake (AghaKouchak et al., 2015; Badescu and Schuiling, 2010). The Aral Sea has dried up over the past several decades and affected the surrounding communities with windblown salt storms (Micklin, 1988). Moreover, the population around Urmia Lake is much larger than around the Aral Sea and thus more people are at risk (UNEP, 2012).

A number of recent papers have discussed reasons for the shrinkage of Urmia Lake and the possible environmental consequences. Delju et al. (2013) showed how a decrease in precipitation combined with an increase in temperature in the basin has caused the most severe drought in the last 40 years. Other studies have assessed the observed precipitation over the basin and have confirmed the decreasing trend (Farokhnia and Morid, 2014; Hassanzadeh et al., 2012; Katiraei PS, 2006; Rezaei Banafsheh M, 2010). A recent investigation showed that Urmia Lake only receives a relatively small amount of groundwater discharge (up to 3 percent) so it is very sensitive to the surface inflow fluctuations (Hashemi, 2011; ULRP, 2015). Hassanzadeh et al. (2012) demonstrated that the decline in surface inflow has been the dominant reason for lake shrinkage. They showed that, in total, $65 \%$ of the decline in lake water levels and volumes had been caused by changes in inflow, which was due to surface water use and climate change. Fathian et al. (2014) showed the correlation between inflow reduction and climate variability (precipitation and temperature). They also estimated that inflow to the lake is more sensitive to temperature than to precipitation. On the other hand, AghaKouchak et al. (2015)'s suggested that human water use has been the most influential factor on the lake desiccation. Although the studies mentioned indicated different factors to be the major contributor to the declining inflow, they all agree that a combination of climate change and water resources development has caused the observed decline. However, the relative contributions of these two drivers has not been quantified so far and it is therefore not clear to what extent climate change and water resources development have contributed to the declining inflow. The aim of this paper is to quantify the relative contributions of climate change and water resources development to the declining inflow into Urmia Lake over the last 50 years.

\section{Study area}

The Urmia Lake basin area is around $51,000 \mathrm{~km}^{2}$, of which the lake formerly covered approximately $5000 \mathrm{~km}^{2}$. Urmia Lake's water level started to decrease sharply from 1995 (Figure 1). Since the lake is shallow (Djamali et al., 2008), the surface area of the lake also shrunk rapidly (Supplementary information 1).

\footnotetext{
${ }^{1}$ In this study, climate change is defined as follows: "A change in the state of the climate that can be identified by changes in the mean and/or the variability of its properties and that persists for an extended period, typically decades or longer. It refers to any change in climate over time, whether due to natural variability or as a result of human activity" IPCC Fourth Assessment Report 2007: Climate Change: Synthesis Report.
} 
There are 17 permanent rivers and 12 seasonal rivers which terminate at Urmia Lake (Figure 2). The basin can be divided into six main subbasins: west, southwest, south, east, north, and northeast. The average annual precipitation in the basin is between 300 and $400 \mathrm{~mm}$. The mean annual air temperatures is reported from 6.8 to $14.8^{\circ} \mathrm{C}$ in summer (Iran Ministry of Energy, 2014a; Karbassi et al., 2010).

The basin has an arid to semi-arid climate; this means that agriculture in the basin is highly dependent on irrigation. There are $~ 510,000$ ha of irrigated land in the basin with 33 modern and traditional irrigation networks. The reported irrigation efficiency is quite low: $37 \%$ for farming and $45 \%$ for gardening (Iran Ministry of Energy, 2014b). To support agricultural growth, the area under irrigation around the lake has increased over seven times during the last 15 years (Iran Ministry of Energy, 2014b). These land cover changes along with climate change put extra pressure on the basin's water resources and have caused a dramatic decline in the inflow to the lake (Hashemi, 2011).

Forty-one small and large reservoirs have been built in the basin since 1970 (Figure 2), storing around 2000×10 $\mathrm{m}^{3}$ water (Iran Ministry of Energy, 2013) (Figure 3). Information about heights, operating purpose, storage capacities, and surface area of all reservoirs were provided by the Iranian Ministry of Energy, Deputy of Water and Wastewater, Macro Planning Bureau (Iran Ministry of Energy, 2013). Of the 511,926 hectares of irrigated lands in the basin, 356,420 hectares (70\%) are farms and 155,506 hectares (30\%) gardens. The land use, irrigation pattern and cropping calendar information was provided by the Urmia Lake Restoration Program.

\section{Method}

\subsection{Data management}

To assess the precipitation trend during study period, we used precipitation data from 146 rain gauges distributed over the basin (Figure 2). Data-quality control and homogenization of precipitation time-series have been done by applying the method described in Vicente Serrano et al. (2010) as reported by the Iran Ministry of Energy (2014c). This method comprises three steps. The first step filled the data gaps using auxiliary information obtained from Iran Meteorological Organization and nearby observatories. The second step identified the records that differed noticeably from values recorded in neighboring stations and replaced anomalous and questionable ones. The third step verified the homogeneity of the data series to avoid the presence of spurious data in the final dataset. Observed annual inflow into the lake for the period 1960-2010 was obtained from 18 hydrometric stations located near the outlets of all important tributaries to the Lake (Figure 2).

\subsection{Hydrological model}

To separate impacts of climate change and water resources development we used the Variable Infiltration Capacity (VIC) model, including reservoir and irrigation modules. The VIC model is a grid-based soilvegetation-atmosphere transfer schemes model (Liang et al., 1994; Nijssen et al., 1997; Nijssen et al., 2001b). The input data are daily precipitation, maximum and minimum temperature and wind speed. Each grid cell is divided into multiple vegetation types and into multiple soil layers. Historical vegetation data were obtained from the SAGE database at the University of Wisconsin-Madison (available online at http://www.sage.wisc.edu/). Evapotranspiration is calculated using the Penman-Monteith equation. The simulated surface streamflow and base flow, combined referred as inflow in this paper, are routed from each grid cell to the basin as described by Lohmann et al. (Lohmann et al., 1998b, 1998a). The VIC model, like most land surface models, does not consider deep groundwater withdrawals (Haddeland et al., 2007), which therefore are not taken into account in this study. The model has been widely used for streamflow studies globally (Nijssen et al., 2001a; Van Vliet et al., 2013) and for major river basins, as well as for other basins of the world like Europe, the US, and China (Hurkmans et al., 2008; Van Vliet et al., 2012; Wu et al., 2007; Xie et al., 2007a). The results of these studies have shown that the model has been able to reproduce the water cycle well. 
Haddeland (2006) added reservoir and irrigation schemes to the VIC model, allowing the model to simulate irrigation water use, based on the calculated soil moisture deficit. The crop evapotranspiration is first calculated within the grid cells based on FAO (Food and Agriculture Organization of the United Nations)'s guideline (Allen et al., 1998). The grid cells are divided into an irrigated and a non-irrigated area. In the model, irrigation is initiated if soil moisture falls below the transpiration level. To calculate irrigated water demand, an initial model run is performed assuming irrigation water is freely available (free irrigation run). Then, another simulation run is performed where irrigation is limited by water available from the first local river runoff, and, if no runoff water is available, water is extracted from reservoirs (Haddeland et al., 2006). The reservoir scheme calculates optimal release based on simulated reservoir inflow, storage capacity, reservoir evaporation, and downstream water demands. The optimal released calculated based on the SCEM-UA algorithm (Vrugt et al., 2003). The model was able to simulate well the main hydrologic impacts of reservoir operations and irrigation water withdrawals on streamflow in different parts of the world (Haddeland et al., 2014; Haddeland et al., 2006).

\subsection{Forcing data}

To force the model, we used global gridded half-degree meteorological Watch Forcing Data (WFD) (Weedon et al., 2011), 1958-2001, and Watch Forcing Data ERA-Interim (WFDEI) (Weedon et al., 2014), 1979-2010. These data sets were specifically developed to be used as meteorological forcing of hydrological models using ERA-40 and ERA-Interim (Dee et al., 2011) reanalysis through consecutive interpolation to half-degree resolution. The elevation correction and monthly-scale adjustments were done based on monthly observations (Weedon et al., 2011). As a result of these corrections the WDF and WFDEI are closer to observations and able to make better assessments of hydrological cycles compared to other available data sets (Weedon et al., 2010). Both datasets were validated with observed data using a Taylor diagram (Bellocchi et al., 2010; Taylor, 2001, 2005) for the overlapping period, 1979 to 2001. The validation was done for precipitation (mm/day), minimum and maximum temperature $\left({ }^{\circ} \mathrm{C}\right)$ for the WFD and WFDEI overlapping period, 1979 to 2001. For precipitation, observed data from 15 stations were used. For maximum and minimum temperature, observed data from seven stations were used. The stations are located homogeneously in the basin and were selected based on data availability for the overlapping period.

\subsection{Model calibration}

We calibrated the VIC model following the methods described by Xie et al. (2007b), using seven runoff-related model parameters, including the infiltration parameter, and the three soil-layer thicknesses. These four parameters were used for the primary calibration. In the advanced stage, the three parameters in the base flow scheme, including the maximum velocity of base flow Dm, fraction of maximum base flow Ds, and fraction of maximum soil moisture content of the third layer Ws, were used.

We calibrated the model for all six subbasins separately, for 1960 to 1970 before the first irrigation and reservoir developments in the basin. After the calibration, we assessed the performance at the stations located furthest downstream, closest to the lake for all six subbasins. To evaluate the accumulation of differences in streamflow volume between simulated and measured data (Moriasi et al., 2007), percent bias (Pbias) was used as objective function for mean monthly average. The correlation coefficient (R) was also selected to show the degree of linearity between observed and simulated data for the same parameter (Hurkmans et al., 2010).

\subsection{Simulation and calculations}

The model was forced with precipitation, maximum and min temperature and wind speed obtained from WFD for 1960-2001 and WFDEI for 2001-2010. The 0.5 degree spatial and daily temporal resolution have been selected for the simulation regarding the forcing data resolution. Streamflow is simulated by routing subsurface and surface runoff using the method described in Lohmann et al. (1998a).

In order to implement the irrigation scheme, the following local information on irrigation water use was used in the model simulations: percentage irrigated area, crop characteristics for each cell, and the cropping calendar. For the reservoir scheme, information for the basin's 41 dams including the locations, height, storage capacity, operating purpose, irrigating area, and surface area (estimated to be $146 \mathrm{~km}^{2}$ in total), were added to the model, from which reservoir evaporation was calculated using the Penman equation in the model (Haddeland, 2006). 
To ascertain the trend in the impact of reservoir and irrigation development, the relevant input was updated four times during the simulations in four development stages: 1960-1970, when there were no reservoirs in the basin; 1970-1995, when the reservoirs and irrigation area started to expand to $900 \times 10^{6} \mathrm{~m}^{3}$ and $370 \times 10^{3}$ ha repectively; 1995-2005, when reservoir capacity increased to $1700 \times 10^{6} \mathrm{~m}^{3}$ and irrigation increased to 430000 ha; and finally 2005-2010, when reservoir capacity increased to $2000 \times 10^{6} \mathrm{~m}^{3}$, and irrigation area increased to almost 510000 ha (Figure 3). The simulation was performed for five different runs. The first run simulated conditions without reservoirs and irrigation (naturalized flow). The second run only simulated reservoir operation in the basin (only reservoir run). To calculate water demand, the third run assumed irrigation water is freely available (free irrigation run). In the fourth run irrigation was limited by water available from local river runoff, and, if no runoff water was available, water was extracted from reservoirs (limited irrigation run). The last run considered both reservoirs and irrigation in the basin (irrigation and reservoir run).

The results were compared to study the role of different factors: climate variability and change, reservoirs, irrigation, and the combination of all factors. Furthermore, by using two approaches, we quantified the effect of climate change and local anthropogenic activities (irrigation and reservoirs) on inflow individually. The first method is based on Wang (2014). By reviewing several methods, he concluded that streamflow can be divided into subseries from a year before human activity is began (baseline period) and after (altered period). Thus, the difference between the mean annual inflow during the altered period and the mean annual inflow during the baseline period $(\Delta Q)$ is the total change of inflow which results from the combined effects of climate change and human activity. Based on this rationale, for this study $\Delta \mathrm{Q}$ can be estimated as:

$$
\begin{aligned}
& \Delta Q=\left(\overline{Q_{a p}}\right)-\left(\overline{Q_{b p}}\right)=\left(\overline{Q_{a p(\text { lrrig-res })}}\right)-\left(\overline{Q_{b p(n a t)}}\right) \\
& \Delta \mathrm{Q}_{\mathrm{c}}=\left(\overline{\left.Q_{a p(n a t)}\right)}-\left(\overline{Q_{b p}(\text { nat })}\right)\right. \\
& \Delta \mathrm{Q}_{\mathrm{h}}=\left(\overline{\left.Q_{a p(\text { lrrlg-res })}\right)}-\left(\overline{Q_{a p(n a t)}}\right)\right.
\end{aligned}
$$

\section{Equation 1}

Where $\Delta \mathrm{Q}_{\mathrm{c}}$ is change in inflow attributed to climate change, $\left(\overline{Q_{a p}}\right)$ is the mean annual inflow during altered period, $\left(\overline{Q_{b p}}\right)$ is the mean annual inflow during baseline period, $\left(\overline{Q_{b p(n a t}}\right)$ is the mean naturalized annual inflow during the baseline period, $\Delta \mathrm{Q}_{\mathrm{h}}$ is change in inflow attributed to water resources management development $\left(\overline{Q_{a p(n a t)}}\right)$, is mean naturalized annual inflow during the altered period, and $\left(\overline{Q_{a p(\text { rrrg-res })}}\right)$ is the mean annual simulated inflow including irrigation and reservoirs during the altered period. The results of this approach is compared with another approach, which is based on the differences between the trends of naturalized flow and inflow considering irrigation and reservoirs for the whole 50 years study period.

The Environmental Flow Requirement (EFR) used in this study are based on the study by Abbaspour and Nazaridoust (2007). They considered $240 \mathrm{~g} / \mathrm{l}$ of $\mathrm{NaCl}$ as the water quality threshold for the survival of Artemia urmiana the key species living in the lake. By using a long-term record of the lake water level and $\mathrm{NaCl}$ concentration data, they estimated the water level of $1274.1 \mathrm{~m}$ a.m.s.l. as the lake ecological level. Based on the lake surface-volume relation, $4.6 \times 10^{9} \mathrm{~m}^{2}$ were estimated as the lake ecological surface area. As Urmia Lake is the terminate lake (no outflow), they concluded that a minimum of $3085 \times 10^{6} \mathrm{~m}^{3}$ (difference between the lake evaporation and precipitation on the estimated ecological surface area) of annual inflow is required to maintain the required ecological level. If the mean annual inflow over a period of several years meets or exceeds the EFR, the lake would continue its normal ecological functions including Artemia reproduction and supporting biodiversity. On the other hand, if salinity rises above $240 \mathrm{~g} / \mathrm{l}$, these functions would be negatively affected. The estimated EFR, $3085 \times 10^{6} \mathrm{~m}^{3}$, has been widely used as a basis for the basin water resources management projects, also defined as the policy target of Urmia Lake Restoration Program (ULRP, 2016a). Therefore, in this study we compared the simulated inflow to this value. 


\section{Results}

\subsection{Forcing data validation}

The Taylor diagram, showing three types of statistical analyses (correlation coefficient, RMSE and standard deviation), was used to compare the WFD and WFDEI with the local observed data (Figure 4). The correlation coefficient for precipitation for both WFD and WFDEI is 0.75 which is generally considered to be strong (Bellocchi et al., 2010). The WFD and WFDEI had almost identical RMSE (19 mm/month) and standard deviation (27 mm/month). For minimum temperature, the correlation coefficient for WFDEI is 0.82 and for WFD 0.9. For maximum temperature the correlation coefficient for WFDEI is 0.87 and for WFD 0.92 . The RMSE is higher for WFDEI compared to WFD.

The Taylor diagram also showed that the simulated datasets perform relatively well in simulating the seasonal pattern for precipitation, minimum temperature and maximum temperature. The gridded datasets perform equally well for precipitation, while WFD performs better than WFDEI regarding minimum and maximum temperatures. Furthermore, WFDEI and WFD showed a very good agreement for their overlapping period (1979-2000).

\subsection{Hydrological model calibration}

The results of model calibration indicated that the model was able to simulate the streamflow quite well for the entire basin ( $\mathrm{r}-.99$ to 0.79 and pbias -25.5 to 25.2) (Figure 5). The model performed better in the western and southern parts of the basin than it did in the north and northeast. This could be due to the water extraction for agriculture in north and northeast (Iran Ministry of Energy, 2014a) which was not included in this stage.

\subsection{Recent climate change and the impact on inflow}

The analysis of mean annual observed precipitation over the basin showed a decreasing trend between 1960 and 2010 from $\sim 390 \mathrm{~mm} /$ year to $\sim 330 \mathrm{~mm} /$ year over the last 50 years. Precipitation over the basin decreased by $1.12 \mathrm{mmyr}^{-1}$ over the study period (Figure 6).

The naturalized streamflow trend was similar to precipitation, but with the more pronounced decreasing trend and a higher inter-annual variability (Figure 7a). The total naturalized inflow into the lake decreased by $\sim 1.5 \times 10^{9} \mathrm{~m}^{3}$ over the last 50 years. The 10 -year averages of annual naturalized inflow were higher than EFR for the entire study period (Figure 8). However, during the dry period, 1995-2001, the naturalized inflow into the lake was generally less than EFR (Figure 7a). In 1999, the inflow reached $1110 \times 10^{6} \mathrm{~m}^{3} \mathrm{yr}^{-1}$, which was the lowest level of the 50-years study period.

\subsection{The impact of reservoir development}

To assess how reservoir operation affected the inflow into the lake, we subtracted the reservoir run results from the naturalized run streamflow results (Figure 9a). Reservoirs generally stored water in wet years and released it in dry years. This pattern was in balance until 1995. The negative impacts became slightly visible after a considerable expansion in reservoir capacity in 2004, which can be due to increase in evaporation from the reservoirs surface area. The mean annual amount of evaporation lost from reservoirs increased from $30 \times 10^{6} \mathrm{~m}^{3} \mathrm{yr}^{-}$ ${ }^{1}$ to $164.2 \times 10^{6} \mathrm{~m}^{3} \mathrm{yr}^{-1}$ over the study period. Although reservoirs did not significantly impacts on annual inflow, they increased water availability in dry months in particular (Figure 7b). Reservoirs did not have much impact on the 10-year averages of annual inflow (Figure 8).

\subsection{The impact of irrigation development}

Irrigation always reduced inflow into the lake (Figure 9b). In wet years, because more water was available, more of it was used for irrigation. However, the percentage of water taken by irrigation in dry years was higher (Figure 9b). Therefore, irrigation increased pressure on the basin's water balance in dry years. During severe dry years irrigation reduced up to $40 \%$ of the inflow into the lake. Furthermore, in summer time, the basin has a serious 
shortage in relation to meeting the irrigation water requirements from surface water (Figure 7b). The negative values in the free irrigation run (Figure $7 \mathrm{~b}$ ) may illustrate a shortage in the supply of irrigation water, meaning pressure on other water resources like groundwater. The average of annual inflow from 2000 to 2010 was less than EFR considering only irrigation (Figure 8).

\subsection{Impacts of water resources development: reservoirs and irrigation combined}

The last run included both irrigation and reservoirs, the results of this run agreed quite well with the observed annual inflow into the lake (Figure 7a). Irrigation and reservoir development always caused inflow reduction into the lake (Figure 9c). However, comparing the 'only irrigation' run with the 'irrigation and reservoirs' run (Figure $9 \mathrm{~b}$ and c) revealed that reservoirs increased inflow in dry years. Developing irrigation and reservoirs combined with the climate change, on average caused 10-year average inflow into the lake to decline from $5202 \times 10^{6} \mathrm{~m}^{3}$ to $2502 \times 10^{6} \mathrm{~m}^{3}$, a $52 \%$ reduction, over the study period (Figure 8). It means that the average of annual inflow from 2000 to 2009 was less than EFR considering both irrigation and reservoirs (Figure 8). The impact of irrigation and reservoirs is more visible during the last 15 years of the study period (Figure 9c).

\subsection{Relative contributions of climate change and water resources development on the declining lake inflow}

The reservoir irrigation run shows that the total average annual inflow reduced by $48 \%$ over the whole study period, 1960-2010. To distinguish between climate change and water resources development impacts using the Wang (2014) approach, we identified the start of the altered period. Our analysis shows that the inflow changing point is 1995, which is the starting year of the main irrigation's expansion (Figure 3). Therefore, we selected 1995 as the beginning of the altered period. Based on Equation 1 the total change of inflow $(\Delta Q)$ between altered and baseline periods is estimated to be $2735 \times 10^{6} \mathrm{~m}^{3}$, for which $1644 \times 10^{6} \mathrm{~m}^{3}$ (about three fifth) is attributed to climate change $\left(\Delta \mathrm{Q}_{\mathrm{c}}\right)$ and $1091 \times 10^{6} \mathrm{~m}^{3}$ (about two fifth) is attributed to water resources development $\left(\Delta \mathrm{Q}_{\mathrm{h}}\right)$.

We also compared the annual trend in inflow from naturalized run with the trend including irrigation and reservoir run over the whole study period. The results show that average naturalized inflow declined by $29 \times 10^{6} \mathrm{~m}^{2} \mathrm{yr}^{-1}$ due to a change in climate (Figure 7a). For the simulations including irrigation and reservoirs, the reduction in inflow was $49 \times 10^{6} \mathrm{~m}^{2} \mathrm{yr}^{-1}$ showing the changes caused by both climate change and water resources development. This indicates that about three fifth of change (29/49) was caused by climate change over the last 50 years and about two fifth was caused by water resources development. In other words, climate change has caused an inflow reduction of $28 \%$ (48\% $\times$ three fifth) over the study period; while water resources development has caused an inflow reduction of $20 \%$ (48\%×two fifth).

\section{Discussion}

In order to support water management to protect Urmia Lake from further environmental degradation, it is important to know what has caused the recent shrinkage of the lake. Other studies identified climate change and water resources development as main driving reasons for Urmia Lake desiccation (Farokhnia, 2015; Fathian et al., 2014; Hashemi, 2011; Hassanzadeh et al., 2012). By selecting a simulation approach, in this study we assessed the relative contributions of these driving reasons to the declining inflow. Our assessment included the analysis of precipitation datasets from 146 gauging stations for the period 1960-2010over the basin. This analysis revealed a decreasing trend over the study period which is in an agreement with other studies that assessed the trend of observed precipitation (Delju et al., 2013; Farokhnia and Morid, 2014; Hassanzadeh et al., 2012; Katiraei PS, 2006; Rezaei Banafsheh M, 2010).

The simulated naturalized river flow trends show a decreasing pattern similar to precipitation. However, the relative decrease in naturalized flows was much higher. This is caused by a relatively low runoff coefficient (Ghashghaei et al., 2013) for the basin. Furthermore, the seasonal and interannual variability of precipitation also have changed significantly over the last two decades (Delju et al., 2013). These longer dry periods can cause more human water extraction. This is also partly why the naturalized inflow declined sharply during the dry period between 1995 and 2001. During this period, flows did not meet EFR, even in the absence of reservoirs 
and irrigation (simulated). This demonstrates the important role of climate change on the inflow to the lake. This finding is consistent with the trend analysis results of Fathian et al. (2014), who suggested that climate variations in Urmia Lake basin have a direct effect in inferring significant trends in river flow.

Direct evaporation from reservoirs increased considerably over the study period due to increase in total reservoir surface area and probably also due to increases in temperature. However, it did not exceed 5 percent of the inflow into Urmia Lake. Therefore, reservoir operation did only had a limited impact on the average inflow into the lake. Reservoirs can both have positive and negative indirect impacts on inflow. Reservoirs could increase streamflow in dry periods by releasing water stored during wet periods. These results are similar to those found by Adam et al. (2007), who showed little effect of reservoirs on annual trends, but considerable intra-annual changes. They also reported a decreasing trend in winter and early spring. This difference can be attributed to the different climatic conditions at Urmia Lake. On the other hand, as most of the reservoirs were built to supply irrigation projects, the effect of reservoirs should not be assessed in isolation, but rather in combination with the accelerating development of irrigated agriculture in the basin. Due to the sharp increase in water demand for irrigation current reservoirs are increasingly unable to meet increasing demand. In fact, many reservoirs are empty because of declined reservoir inflow. The findings of this study are consistent with the previous study by Fathian (2014), who examined the effect of three large dams in Urmia basin on the inflow. They reported no correlation between the dams operation and annual inflow (Fathian et al., 2014).

Irrigation had a negative impact on inflow and also on water availability throughout the Urmia Lake basin. Moreover, the combination of irrigation and reservoirs has reduced the inflow into the lake if compared to a situation with irrigation only (without reservoirs). This is explained by additional water being stored in reservoirs for supplying water for irrigated fields. However, for dry years the simulated inflow was higher than the simulated inflow into Urmia Lake including irrigation only (without reservoirs), thus showing the potential role of reservoirs managing water in times of water scarcity.

The average annual inflow dropped by 48\% between the years 1960 and 2010. The decreasing trend has been even more pronounced since 1995 when the lake did not receive its EFR during a sequence of years due to a severe drought which was exacerbated by water use for irrigation. To compare and quantify the roles of climate change and human activities on inflow reduction different factors have to be taken into account. Naturalized flow is a function of time, and water resources development is mainly a function of different development stages, so several uncertainties are involved. In this study, we selected two approaches to quantify the distinct role of climate change and water resources development. The first approach was based on assessing the change in inflow before and after substantial human impact. The second one compared the naturalized inflow trend with inflow considering irrigation and reservoirs trend for the whole study period, 1960-2010. Both approaches led to very similar results. Climate change was the main contributor to the inflow reduction (about three fifth) and caused an inflow reduction of $28 \%$ over the study period. Shadkam et al. (2016) assessed the impact of a lowest and highest representative concentration pathways (RCPs) (Moss et al., 2010) on the inflow to Urmia Lake in next century. Their results showed that the effect of climate change is likely to continue in both lowest and highest scenarios. Therefore, the detected trend in this study is likely to belong to a long term change in the climate in this area. Our results also showed that water resources development had a substantial effect on the inflow reduction as well (about two fifth of the reduction, corresponding to $20 \%$ of the original annual average inflow, thus representing the remainder of the $48 \%$ drop). Our findings supports other studies that have indicated that a combination of climate change and water resources development have caused the lake degradation (Farokhnia, 2015; Fathian et al., 2014; Hassanzadeh et al., 2012). AghaKouchak et al (2015) suggested that human water extraction may be the main reason for the lake shrinkage. However, their results are based on assessing the basin Standardized Precipitation Index; while, the current study results are based on assessing simulated inflow into the lake. Furthermore, another explanation can be difference between satellitebased data, used in their study, and meteorological WFD/EI data, used and validated specifically for Urmia basin in this study, also the length of the data. Furthermore, other studies showed that inflow into Urmia Lake is more sensitive to changes in temperature (Farokhnia and Morid, 2014; Fathian et al., 2014) rather than precipitation which have been used to force the model in the current study any may leaded to the different conclusion. The results of this study confirm the results obtained by Farokhnia (2015) who compared the impact of climate 
change and human water use on Urmia Lake inflow with three different methods. Their results indicated that climate change was the dominate reason (up to $72 \%$ ) to reduce the lake inflow.

The models result could be affected by different uncertainties. Firstly, the relatively coarse spatial resolution used for model simulations. Nevertheless, the VIC model was able to simulate the observed streamflow well (Figure 5 and 7a). It was not possible to develop a forcing data set at finer resolution for all variables required (precipitation, temperature and wind speed) due to limited availability of observations and the lack of bias corrected forcing datasets other than WFD/EI. However, we included detailed local information about the reservoir characteristics, land use, and irrigation pattern into the reservoir and irrigation modules. As the focus of this study was on the assessment of total annual flows, the resolution uncertainty is expected to be of limited influence on the reliability of our conclusions.

Secondly, the observed data including precipitation, reservoirs storage and irrigation pattern which provided by the Ministry of Energy. However, they are the best available data based on our best knowledge which have been verified by Urmia Lake Restoration Program (ULRP, 2016b). Furthermore, the observed inflow data which were provided by the ULRP from 18 stations located near the outlets of all important tributaries to the Lake. The estimate of the inflow into Urmia Lake might be inaccurate due to two reasons. First, part of the measured flow does may not actually reach the lake (i.e. due to evaporation). Second, direct runoff into the lake and inflow through small seasonal streams has not been accounted for in our estimate.

Thirdly, we focused our simulation on the use of surface water although a part of the irrigated water use in the basin originates from groundwater. This might cause the minor differences between observed data and simulated results. The streamflow simulated by the VIC model results from water balance calculations on the land surface including shallow rechargeable groundwater through sub-surface runoff. As a result withdrawal from the shallow renewable groundwater is included in our simulations. However this is not the case for deep non-renewable groundwater. The simulated availability of water is therefore probably slightly underestimated (Hanasaki et al., 2008). Our results also indicate that currently surface water cannot meet all irrigation water requirements. It is likely; however, that part of the deficit was met by using deep groundwater.

In this study we compared simulated inflow with used EFR estimated by (Abbaspour and Nazaridoust, 2007), as it has been defined as Urmia Lake Restoration Program target (ULRP, 2016a). The study is based on the assumption that 240 (g/l) NaCl is the threshold that Atemia urmiuana can tolerate. However, Agh (2007) reported the negative impact on survival, growth and reproductive of Artemia urmania at salinity levels ranging from 75 to $175 \mathrm{~g} / \mathrm{l}$ in a 23-day long experiment. Higher salt concentration were not tested, but analyses of other species of Artemia reported no survival above $230 \mathrm{~g} / \mathrm{l}$ (Browne and Hoopes, 1990). Therefore, an in-depth study to review the Urmia Lake environmental flow requirement is recommended.

It is also recommended that further studies consider the volatile geomorphological situation of the lake. Due to the recent reduction in lake volume the salinity of the lake water has increased sharply causing about 8 billion tons of salt to fill up the deeper parts of the lake. A recent investigation by ULRP revealed that the depth of the deepest part of the lake changed from $16 \mathrm{~m}$ to only $2 \mathrm{~m}$ over the period 1995-2015. Although the drop in water level was only around $7 \mathrm{~m}$, a layer of salt of around $7 \mathrm{~m}$ as well, has filled up the deeper parts of the lake. The ratio of the area to the volume $\left(\mathrm{m}^{2} / \mathrm{m}^{3}\right)$ has thus increased considerably, meaning that for the same volume of water much more evaporation is expected.

\section{Conclusions}

Our results show that the recent Urmia Lake degradation was probably caused by reductions in river inflow into the lake due to a combination of changes in the climate and water resources development. Climate change was the main contributor to this inflow reduction. However, water resources development, particularly water use for irrigation, has played a substantial role as well. The results of this study show that urgent action is needed to rehabilitate and preserve the Urmia Lake. This urgent action should include both international action to mitigate climate change impact, and national action to improve water management, in particular to lower the consumptive 
water use for irrigation. It is also recommended that further studies are conducted for increasing our understanding on environmental flow requirement, the effect of the changing lake geomorphology, and the effect of groundwater extraction, as this can importantly contribute to finding a realistic solution for the Urmia Lake socio-environmental disaster.

\section{Acknowledgements}

We would like to express our appreciation for the helpful cooperation of Amin Roozbahani, Urmia Lake Restoration Program Head of Research Division, also Iran Ministry of Energy, Deputy of Water and Wastewater, Macro Planning Bureau for providing us the required data for this study. We would like to thank Ingjerd Haddeland for his efforts in developing the irrigation-reservoir scheme and providing the required files, information, and tutorial. We are also very grateful to the JGLR editors and referees, especially, Prof. Barry Lesht, for their insightful and astute comments on the earlier version of this paper. The first author acknowledges financial support from Wageningen University.

\section{References}

IPCC Fourth Assessment Report 2007: Climate Change: Synthesis Report.

Abbaspour, M., and A. Nazaridoust. 2007. Determination of environmental water requirements of Lake Urmia, Iran: an ecological approach. Int. J. Environ. Stud. 64(2): 161-169.

Adam, J. C., I. Haddeland, F. Su, and D. P. Lettenmaier. 2007. Simulation of reservoir influences on annual and seasonal streamflow changes for the Lena, Yenisei, and Ob'rivers. J Geophys Res 112(D24): D24114.

Agh, N. 2007. Characterization of Artemia populations from Iran. Aristotle University of Thessaloniki, Greece. AghaKouchak, A., H. Norouzi, K. Madani, A. Mirchi, M. Azarderakhsh, A. Nazemi, N. Nasrollahi, A. Farahmand, A. Mehran, and E. Hasanzadeh. 2015. Aral Sea syndrome desiccates Lake Urmia: Call for action. J. Great Lakes Res. 41(1):307-311.

Allen, R. G., L. S. Pereira, D. Raes, and M. Smith. 1998. Crop evapotranspiration-Guidelines for computing crop water requirements-FAO I rrigation and drainage paper 56. FAO, Rome 300(9).

Badescu, V., and R. D. Schuiling. 2010. Aral sea; irretrievable loss or Irtysh imports? Water Resour. Manage. 24(3):597-616.

Bellocchi, G., M. Rivington, M. Donatelli, and K. Matthews. 2010. Validation of biophysical models: issues and methodologies. A review. Agron Sustain Dev 30(1):109-130.

Browne, R. A., and C. W. Hoopes. 1990. Genotype diversity and selection in asexual brine shrimp (Artemia). Evolution: 1035-1051.

Dee, D., S. Uppala, A. Simmons, P. Berrisford, P. Poli, S. Kobayashi, U. Andrae, M. Balmaseda, G. Balsamo, and P. Bauer. 2011. The ERA Interim reanalysis: Configuration and performance of the data assimilation system. Q J R Met Soc 137(656):553-597.

Delju, A., A. Ceylan, E. Piguet, and M. Rebetez. 2013. Observed climate variability and change in Urmia Lake Basin, Iran. Theor Appl Clim 111(1-2):285-296.

Djamali, M., J.-L. de Beaulieu, M. Shah-hosseini, V. Andrieu-Ponel, P. Ponel, A. Amini, H. Akhani, S. A. Leroy, L. Stevens, and H. Lahijani. 2008. A late Pleistocene long pollen record from Lake Urmia, NW Iran. Quatern. Res. 69(3): 413-420.

Farokhnia, A. 2015. I mpact of land use change and climate variability on Urmia basin Hydrology. Dissertation. Tarbiat Modares University, Agricultral department.

Farokhnia, A., and S. Morid. 2014. Assessment of the Effects of Temperature and Precipitation Variations on the Trend of River Flows in Urmia Lake Watershed. J water wastewater 25(91):86-97.

Fathian, F., S. Morid, and E. Kahya. 2014. Identification of trends in hydrological and climatic variables in Urmia Lake basin, Iran. Theor Appl Clim: 1-22.

Ghashghaei, M., A. Bagheri, and S. Morid. 2013. Rainfall-runoff Modeling in a Watershed Scale Using an Object Oriented Approach Based on the Concepts of System Dynamics. Water Resour. Manage. 27(15):5119-5141. Haddeland, I. 2006. Anthropogenic impacts on the continental water cycle. Dissertation. University of Oslo, Department of Geosciences.

Haddeland, I., T. Skaugen, and D. P. Lettenmaier. 2006. Anthropogenic impacts on continental surface water fluxes. Geophys. Res. Lett. 33(8).

Haddeland, I., T. Skaugen, and D. Lettenmaier. 2007. Hydrologic effects of land and water management in North America and Asia. Hydro Earth Sys Sci 11(2):1035-1045.

Haddeland, I., J. Heinke, H. Biemans, S. Eisner, M. Flörke, N. Hanasaki, M. Konzmann, F. Ludwig, Y. Masaki, and J. Schewe. 2014. Global water resources affected by human interventions and climate change. Proceedings of the National Academy of Sciences 111(9):3251-3256.

Hanasaki, N., S. Kanae, T. Oki, K. Masuda, K. Motoya, N. Shirakawa, Y. Shen, and K. Tanaka. 2008. An integrated model for the assessment of global water resources-Part 2: Applications and assessments. Hydro Earth Sys Sci 12(4): 1027-1037.

Hashemi, M. 2011. A socio-technical assessment framework for integrated water resources management (IWRM) in Lake Urmia Basin, Iran.

Hassanzadeh, E., M. Zarghami, and Y. Hassanzadeh. 2012. Determining the main factors in declining the Urmia Lake level by using system dynamics modeling. Water Resour. Manage. 26(1): 129-145. 
Hurkmans, R., H. De Moel, J. Aerts, and P. Troch. 2008. Water balance versus land surface model in the simulation of Rhine river discharges. Water Resour Res 44(1).

Hurkmans, R., W. Terink, R. Uijlenhoet, P. Torfs, D. Jacob, and P. A. Troch. 2010. Changes in streamflow dynamics in the Rhine basin under three high-resolution regional climate scenarios. J. Clim. 23(3):679-699. IPCC. 2014. Climate Change 2014: Impacts, Adaptation, and Vulnerability. Working Group II Contribution to the IPCC 5th Assessment Report - Changes to the Underlying Scientific, Summary for Policymakers. http://www.ipcc.ch/report/ar5/wg2/.

Iran Ministry of Energy, Deputy of Water and Wastewater, Macro Planning Bureau. 2013. The National Water Master Plan Study in the Aras, Sefidrood, between Sefidrood and Haraz, Atrac and Urmia Water allocation for the development projects in Urmia Lake basin, Report Number:2385070-2050-24142. 2385070-2050-24142. I ran Ministry of Energy, Deputy of Water and Wastewater, Macro Planning Bureau. 2014a. The National Water Master Plan Study in the Aras, Sefidrood, between Sefidrood and Haraz, Atrac and Urmia: Agricultural Water Use Study in Urmia Lake Basin, Report Number: 2385070-4420-19464. 2385070-4420-19464.

I ran Ministry of Energy, Deputy of Water and Wastewater, Macro Planning Bureau. 2014b. The National Water Master Plan Study in the Aras, Sefidrood, between Sefidrood and Haraz, Atrac and Urmia Basins, Volume 19: Agricultral development for 2040 Horizion, Report number: 3385070-250.

I ran Ministry of Energy, Deputy of Water and Wastewater, Macro Planning Bureau. 2014c. The National Water Master Plan Study in the Aras, Sefidrood, between Sefidrood and Haraz, Atrac and Urmia Basins, Volume 2: Meteorology, Report number: 2385070-250-22603.

Kakahaji, H., H. D. Banadaki, A. Kakahaji, and A. Kakahaji. 2013. Prediction of Urmia Lake Water-Level Fluctuations by Using Analytical, Linear Statistic and Intelligent Methods. Water Resour. Manage. 27(13):4469 4492.

Karbassi, A., G. N. Bidhendi, A. Pejman, and M. E. Bidhendi. 2010. Environmental impacts of desalination on the ecology of Lake Urmia. J. Great Lakes Res. 36(3):419-424.

Katiraei PS, H. S., I ran Nejad P. 2006. Frequency changes and intensity of daily precipitation in trend precipitation of I ran during 1960 to 2001. Journal of Geophysics and Space (in Persian) 33 (1).

Liang, X., D. P. Lettenmaier, E. F. Wood, and S. J. Burges. 1994. A simple hydrologically based model of land surface water and energy fluxes for general circulation models. Journal of Geophysical Research: Atmospheres (1984-2012) 99(D7): 14415-14428.

Lohmann, D., E. Raschke, B. Nijssen, and D. Lettenmaier. 1998a. Regional scale hydrology: I. Formulation of the VIC-2L model coupled to a routing model. Hydro Sci J 43(1): 131-141.

Lohmann, D., E. Raschke, B. Nijssen, and D. Lettenmaier. 1998b. Regional scale hydrology: II. Application of the VIC-2L model to the Weser River, Germany. Hydro Sci J 43(1):143-158.

Micklin, P. P. 1988. Desiccation of the Aral Sea: a water management disaster in the Soviet Union. Science 241(4870): 1170-1176.

Moriasi, D., J. Arnold, M. Van Liew, R. Bingner, R. Harmel, and T. Veith. 2007. Model evaluation guidelines for systematic quantification of accuracy in watershed simulations. Trans ASABE 50(3):885-900.

Moss, R. H., J. A. Edmonds, K. A. Hibbard, M. R. Manning, S. K. Rose, D. P. Van Vuuren, T. R. Carter, S. Emori, M. Kainuma, and T. Kram. 2010. The next generation of scenarios for climate change research and assessment. Nature 463(7282): 747-756

Nijssen, B., D. P. Lettenmaier, X. Liang, S. W. Wetzel, and E. F. Wood. 1997. Streamflow simulation for continental-scale river basins. Water Resour Res 33(4): 711-724.

Nijssen, B., G. M. O'Donnell, D. P. Lettenmaier, D. Lohmann, and E. F. Wood. 2001a. Predicting the discharge of global rivers. J. Clim. 14(15):3307-3323.

Nijssen, B., R. Schnur, and D. P. Lettenmaier. 2001b. Global retrospective estimation of soil moisture using the variable infiltration capacity land surface model, 1980-93. J. Clim. 14(8):1790-1808.

Rezaei Banafsheh M, S. F., Jalali T. 2010. Investigation of the trend analysis of extreme value of daily temperature and precipitation in Urmia Lake basin. J Geo Plan (in Persian) 38(16):43-74.

Shadkam, S., F. Ludwig, M. T. van Vliet, A. Pastor, and P. Kabat. 2016. Preserving the world second largest hypersaline lake under future irrigation and climate change. Sci. Total Environ. 559:317-325.

Taylor, K. E. 2001. Summarizing multiple aspects of model performance in a single diagram. Journal of Geophysical Research: Atmospheres (1984-2012) 106(D7): 7183-7192.

Taylor, K. E. 2005. Taylor diagram primer. PCMDI.

Urmia Lake Restoration Program (ULRP). 2015. The interaction of coastal aquifers by Urmia Lake. ULRP-Rep Task Force-GW Interaction.

Urmia Lake Restoration Program (ULRP). 2016a. Approved solutions, the executive status and progress of projects (2).

Urmia Lake Restoration Program (ULRP). 2016b. Urmia Lake information and graphs. Available at: http://ulrp.sharif.ir/page/urmia-lake-level.

United Nations Environment Program (UNEP). 2012. The Drying of I ran's Lake Urmia and its Environmental Consequences. http://na.unep. net/geas/getUNEPPageWithArticlel DScript.php?article id =79.

Van Vliet, M., J. R. Yearsley, F. Ludwig, S. Vögele, D. P. Lettenmaier, and P. Kabat. 2012. Vulnerability of US and European electricity supply to climate change. Nat Clim Ch 2(9):676-681.

Van Vliet, M., W. H. Franssen, J. R. Yearsley, F. Ludwig, I. Haddeland, D. P. Lettenmaier, and P. Kabat. 2013. Global river discharge and water temperature under climate change. Global Environ. Change.

Vicente Serrano, S. M., S. Beguería, J. I. López Moreno, M. A. García-Vera, and P. Stepanek. 2010. A complete daily precipitation database for northeast Spain: reconstruction, quality control, and homogeneity. Int J Climatology 30(8): 1146-1163.

Vrugt, J. A., H. V. Gupta, W. Bouten, and S. Sorooshian. 2003. A Shuffled Complex Evolution Metropolis algorithm for optimization and uncertainty assessment of hydrologic model parameters. Water Resour Res $39(8)$. 
Wang, X. 2014. Advances in separating effects of climate variability and human activity on stream discharge: An overview. Advances in Water Resources 71:209-218.

Weedon, G., S. Gomes, P. Viterbo, H. Österle, J. Adam, N. Bellouin, O. Boucher, and M. Best. 2010. The

WATCH forcing data 1958-2001: A meteorological forcing dataset for land surface and hydrological models.

WATCH, editor. WATCH Technical Report 22.

Weedon, G., S. Gomes, P. Viterbo, W. Shuttleworth, E. Blyth, H. Österle, J. Adam, N. Bellouin, O. Boucher, and M. Best. 2011. Creation of the WATCH Forcing Data and Its Use to Assess Global and Regional Reference Crop Evaporation over Land during the Twentieth Century. J Hydrometeorology 12(5).

Weedon, G. P., G. Balsamo, N. Bellouin, S. Gomes, M. J. Best, and P. Viterbo. 2014. The WFDEl meteorological forcing data set: WATCH Forcing Data methodology applied to ERA-Interim reanalysis data. Water Resour Res 50(9): 7505-7514.

Wu, Z., G. Lu, L. Wen, C. A. Lin, J. Zhang, and Y. Yang. 2007. Thirty-five year (1971-2005) simulation of daily soil moisture using the variable infiltration capacity model over China. Atmosphere-Ocean 45(1):37-45.

Xie, Z., F. Yuan, Q. Duan, J. Zheng, M. Liang, and F. Chen. 2007a. Regional parameter estimation of the VIC land surface model: Methodology and application to river basins in China. J Hydrometeorology 8(3):447-468. Xie, Z., F. Yuan, Q. Duan, J. Zheng, M. Liang, and F. Chen. 2007b. Regional Parameter Estimation of the VIC Land Surface Model: Methodology and Application to River Basins in China. J Hydrometeorology 8(3). 
Figures captions

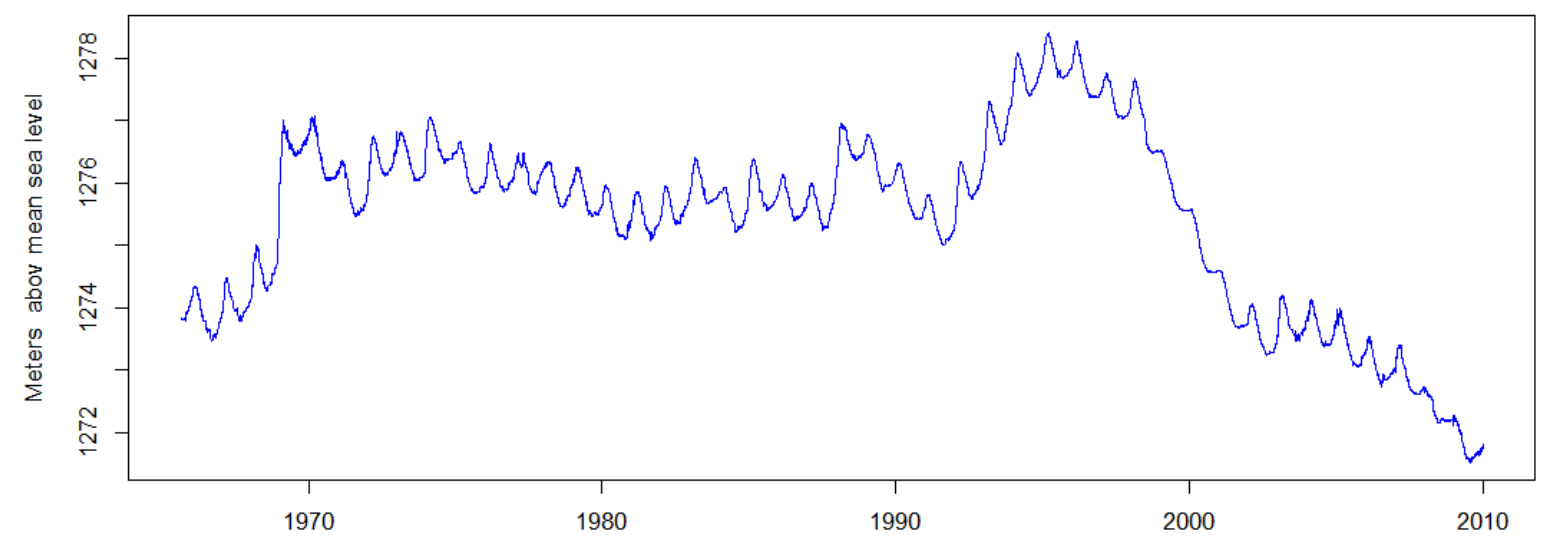

Fig 1 Urmia Water level for the period 1965-2010 (data provided by Urmia Lake Restoration Program Program) 


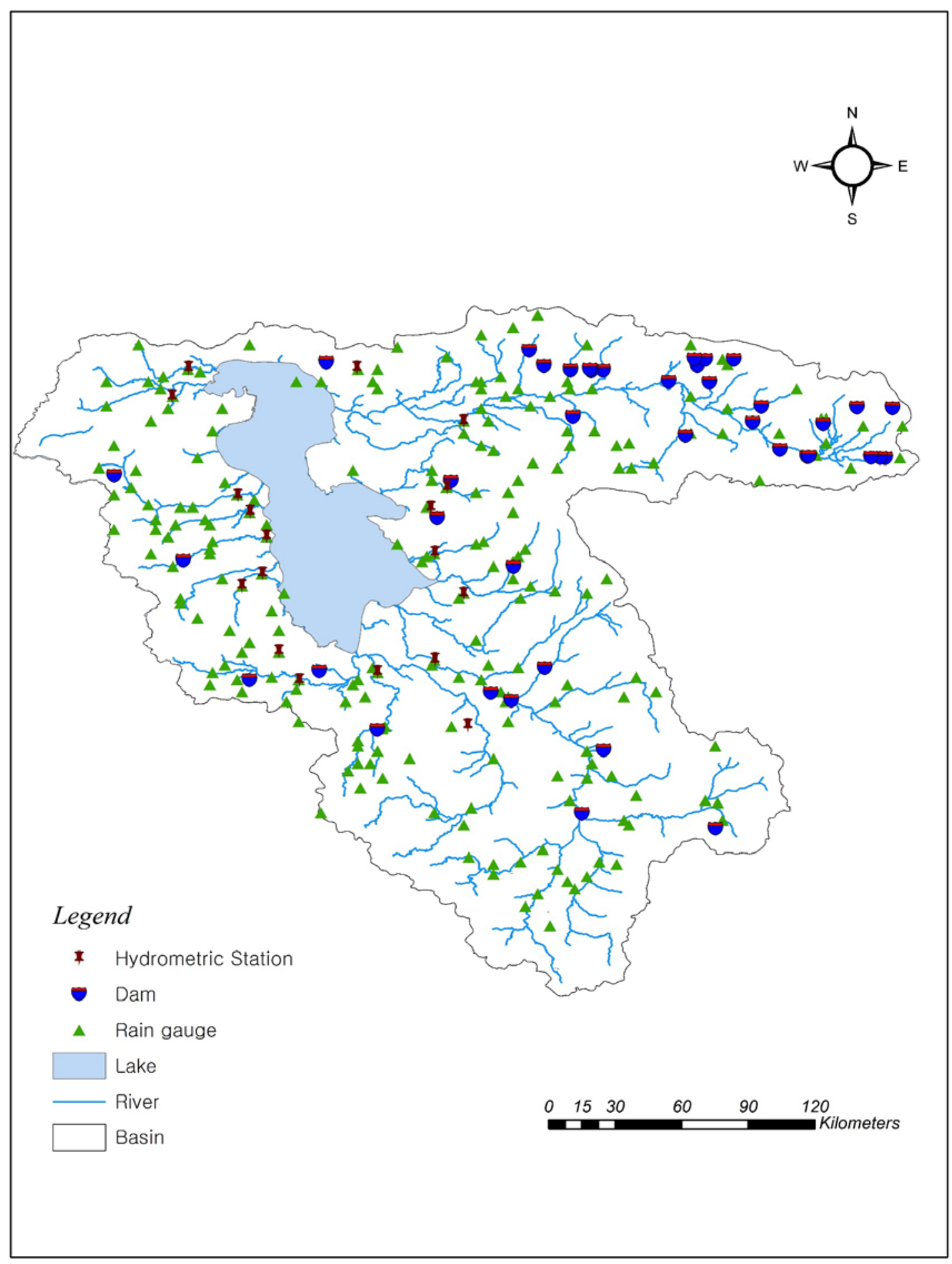

Fig 2 the location of dams (41), rain gauge (146) and hydrometric stations (18) in Urmia basin 


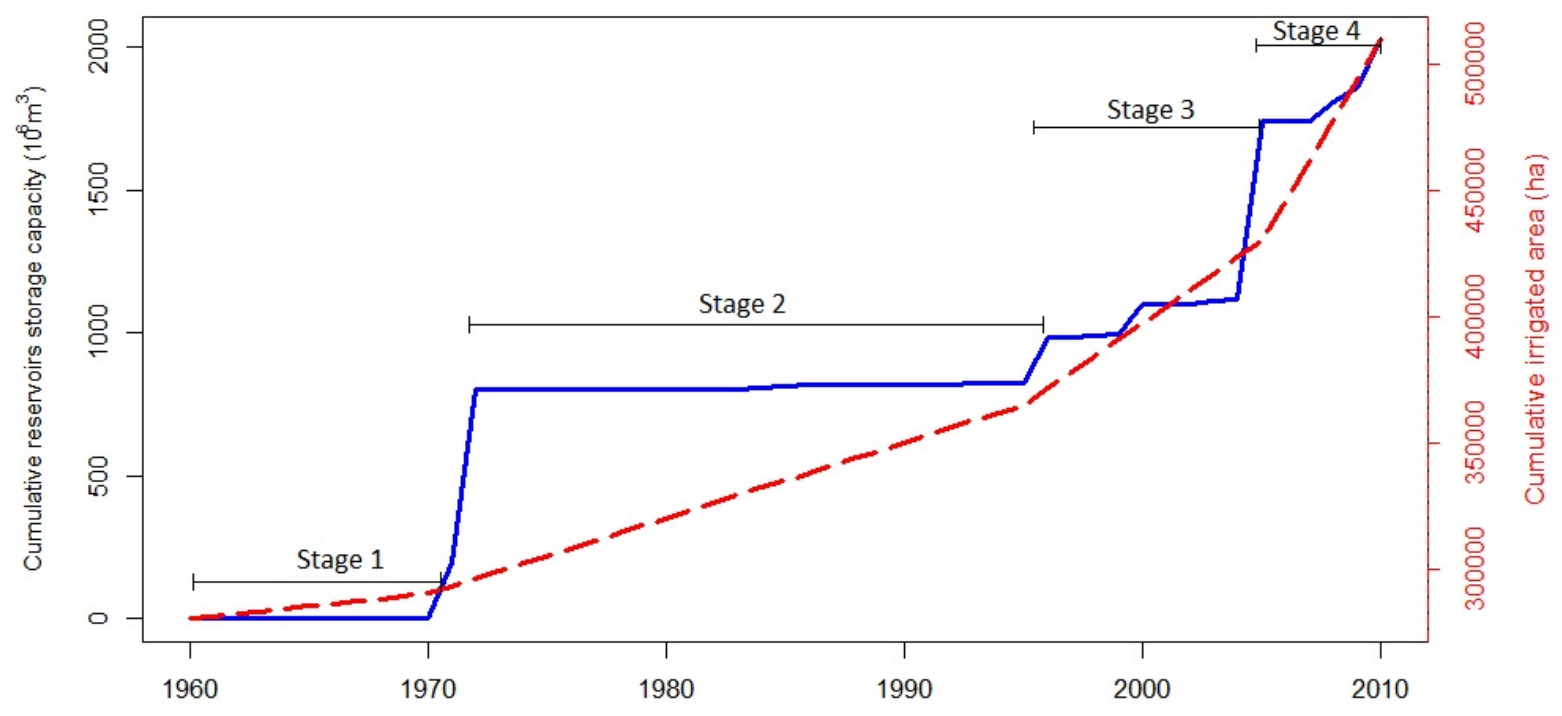

Fig 3 Accumulated storage capacity of reservoirs and cumulative irrigation area with four distinguished water resources development stages, 1960-1970, 1970-1995, 1995-2005, 2005-2010, in Urmia basin
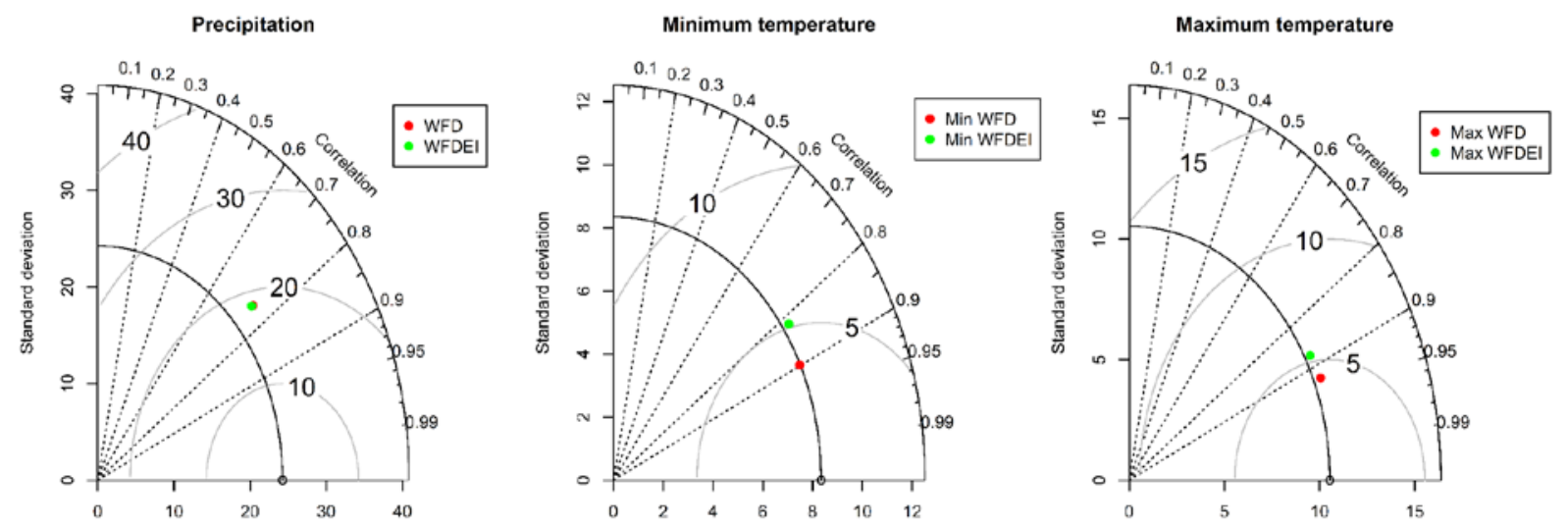

Fig 4 Taylor diagram comparing WFD and WFDEI with observed data for a) monthly precipitation (mm/day) , b) maximum temperature $\left({ }^{\circ} \mathrm{C}\right)$, and c) minimum temperature $\left({ }^{\circ} \mathrm{C}\right)$ 

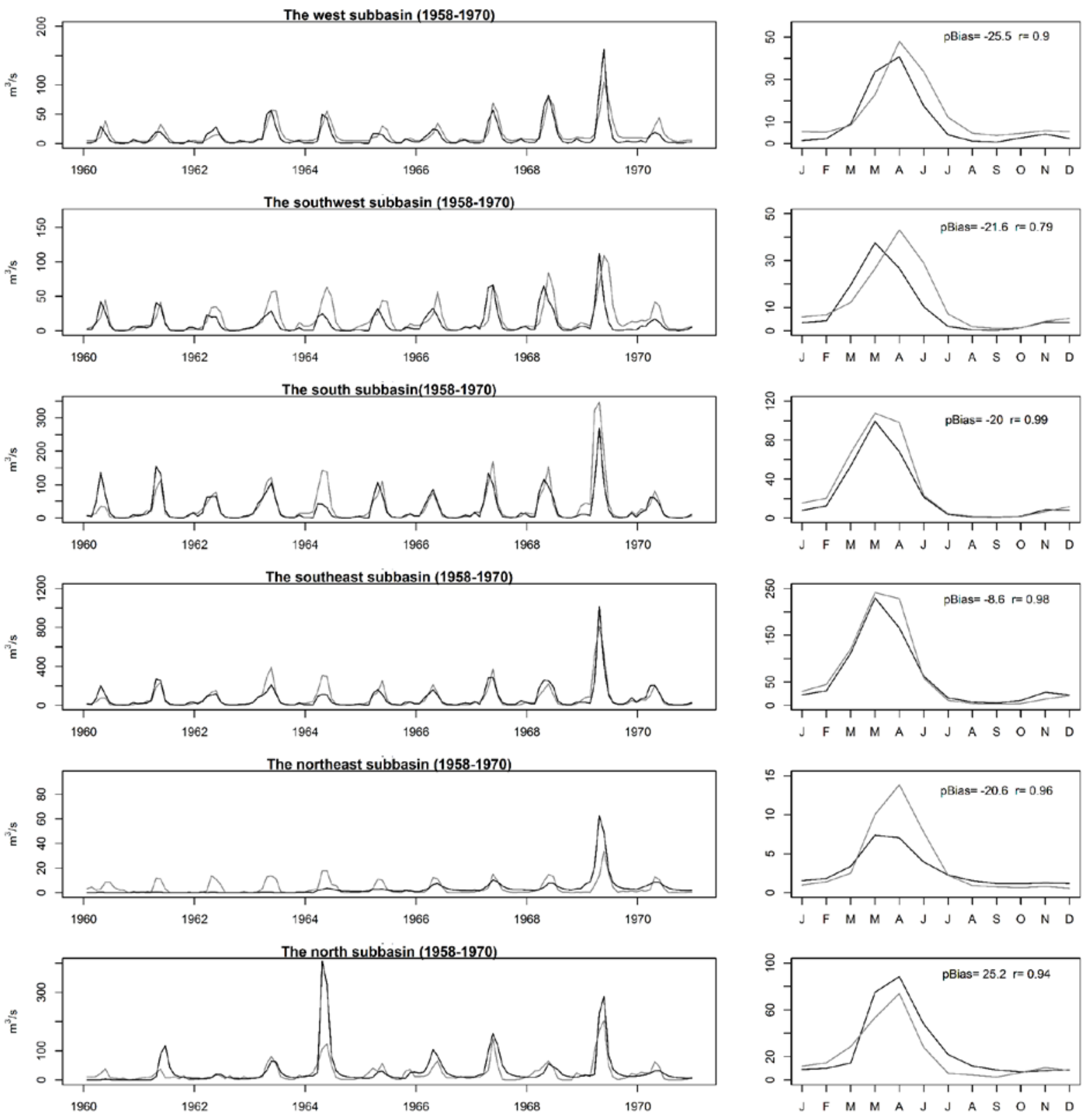

Fig 5 Calibration results for monthly time series for 1960-1970 and mean annual cycles of observed and simulated streamflow data for all six subbasins of Urmia basin 


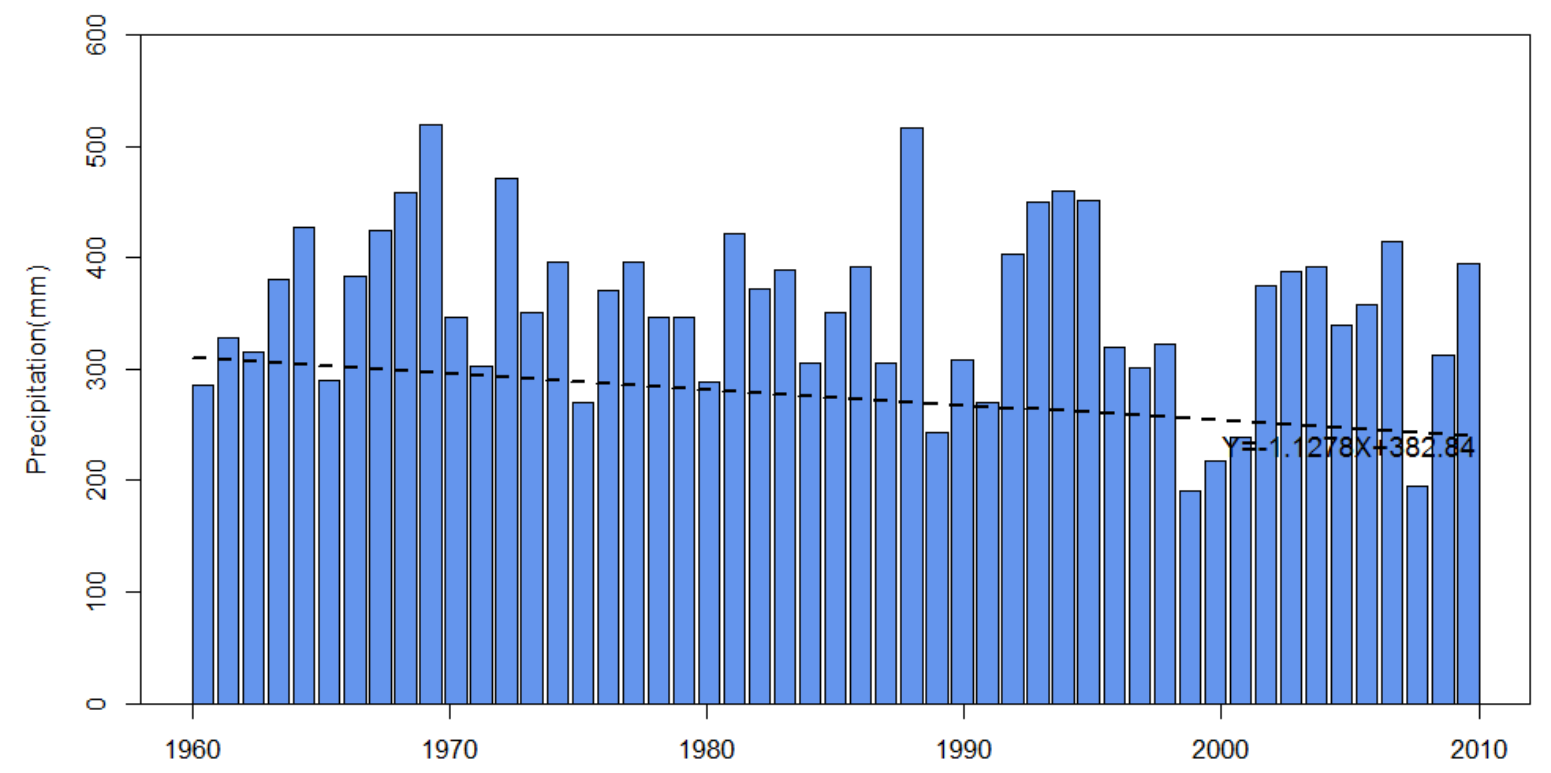

Fig 6 Observed mean annual precipitation over the basin obtained from 146 stations (1960-2010), the dashed straight lines indicate related linear regressions
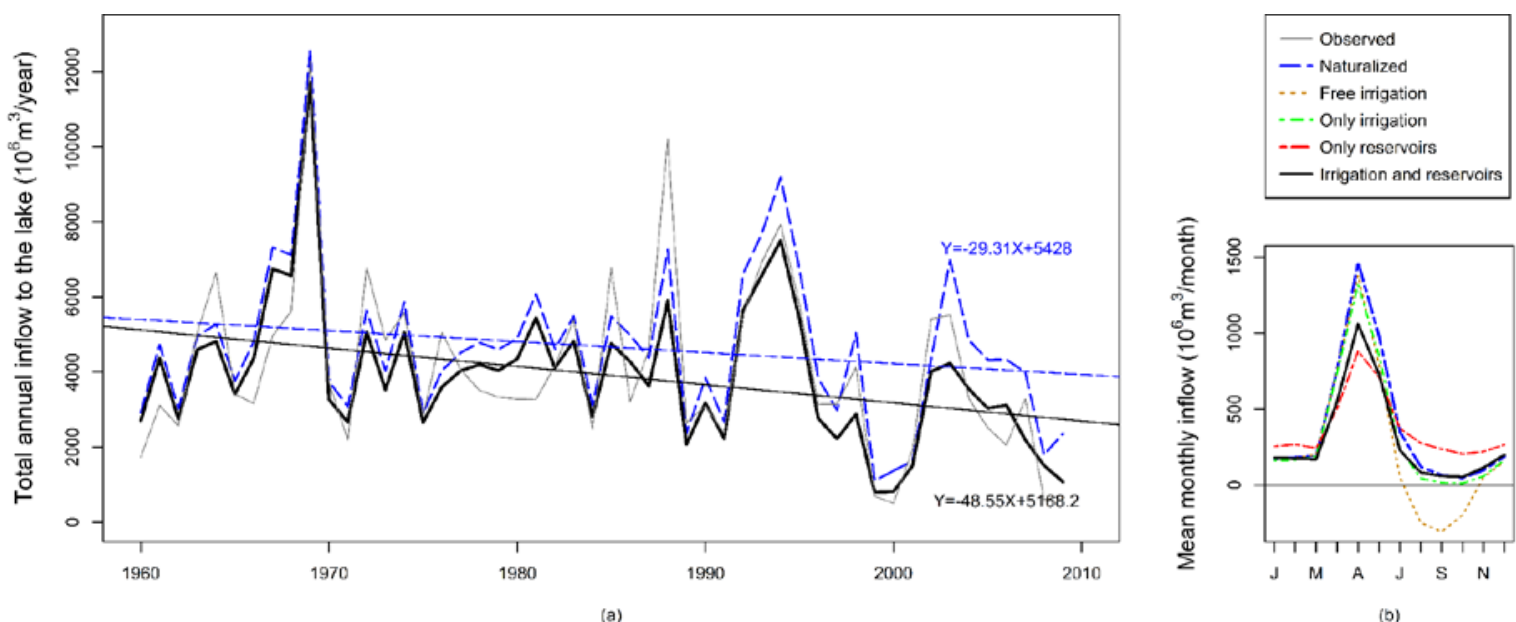

Fig 7 a) Simulated and observed total annual inflow into the lake. Inflow was simulated for naturalized conditions and including irrigation and reservoir. The dashed straight lines indicate related linear regressions for naturalized and irrigation and reservoir run. b) The mean monthly inflow, into the lake for naturalized run and runs including only reservoir, only irrigation (limited and free), and combined irrigation and reservoir run 


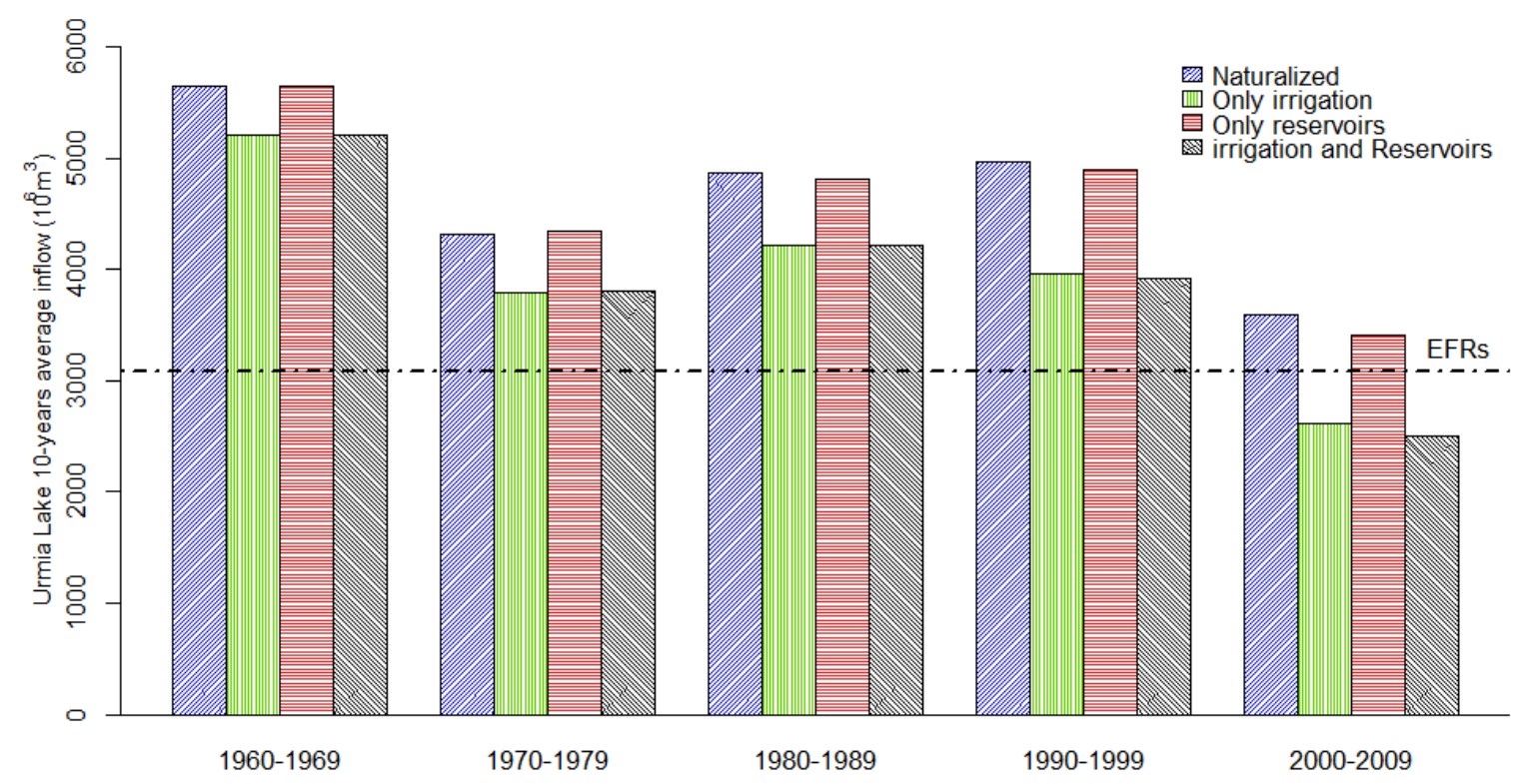

Fig 8 The 10-year average inflow to the lake, dash lines represents the Environmental Flow Requirements, $3085 \times 10^{6} \mathrm{~m}^{3}$, for Urmia basin calculated by Abbaspour and Nazaridoust (2007)
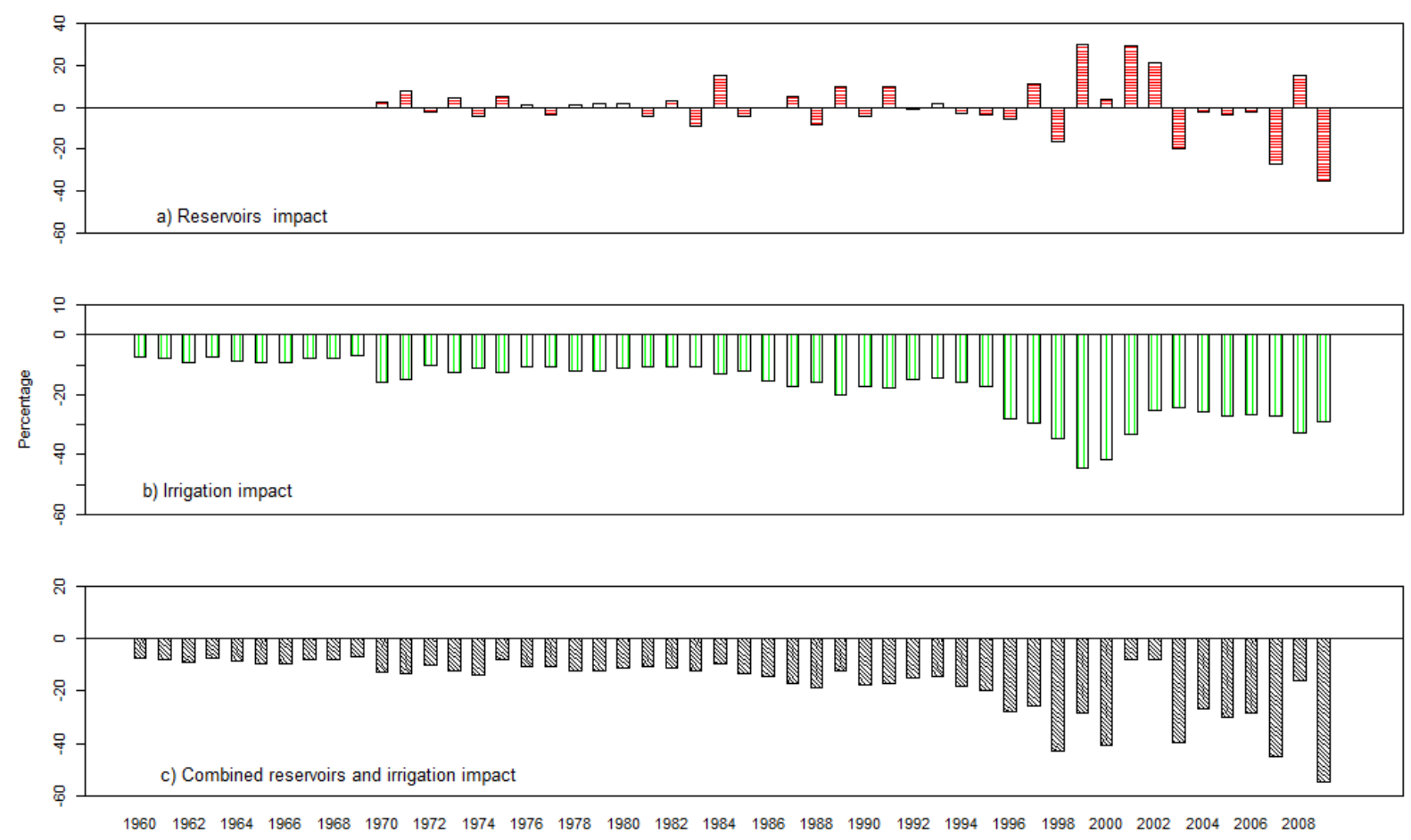

Fig 9 The fraction of inflow which compared with the naturalized inflow in model with a) only reservoir, b) only limited irrigation, c) combined reservoir and irrigation 


\section{Supplementary information}

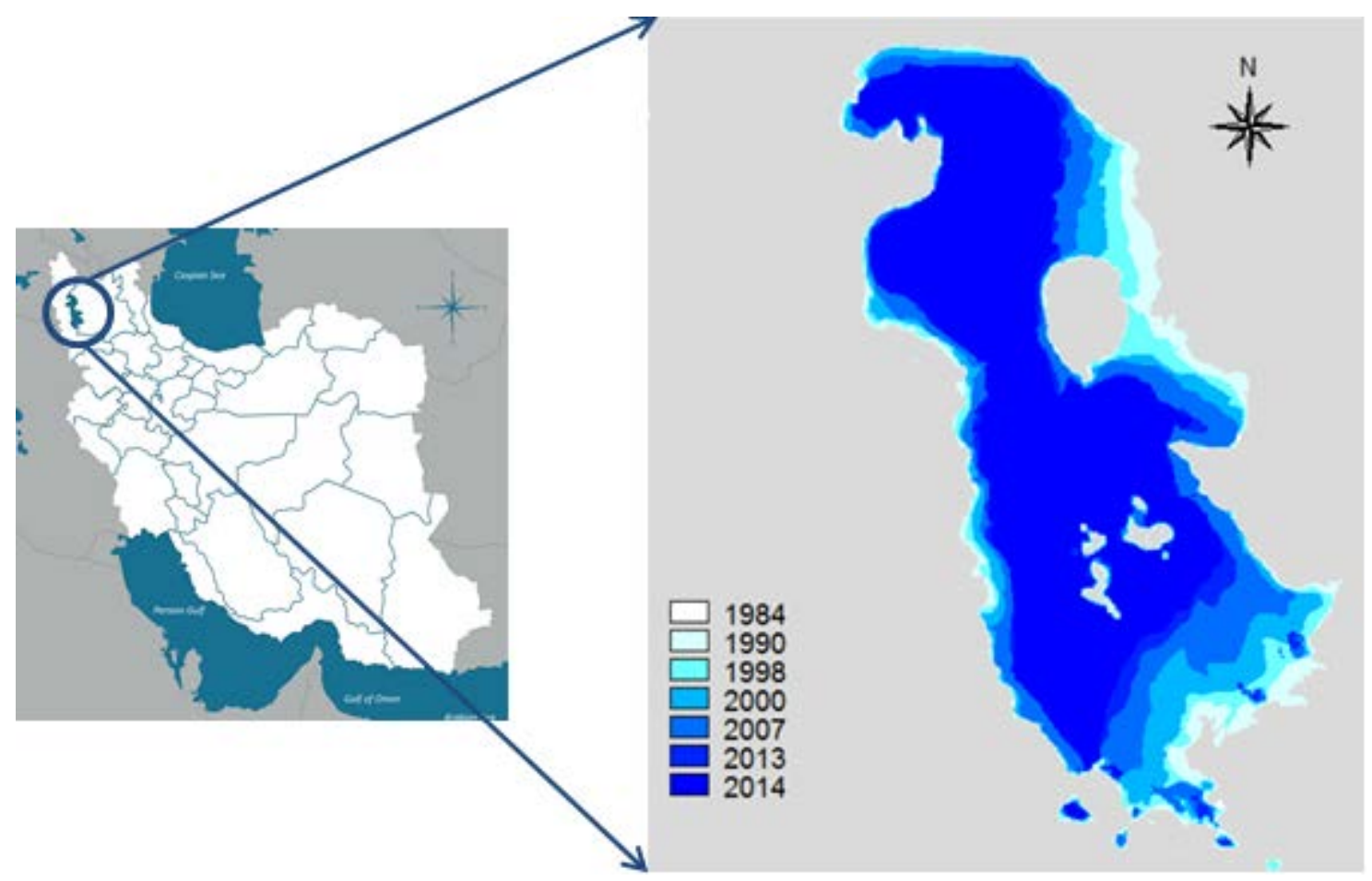

SI 1Urmia basin location (a) and the surface area changes from 1984 to 2014, derived from LandSat imagery (b) (Shadkam et al., 2016) 